\section{Komplexe Schlafapnoe}

Helga Peter

Marburg, Deutschland

\section{Englischer Begriff}

complex sleep apnea

\section{Definition}

Siehe $\triangleright$,Zentrale Schlafapnoe unter Therapie“. 